\title{
The Effect of Industrial and Chemical Products on Breast Milk Content
}

\author{
Nuray Dilek (Corresponding author) \\ Istanbul University-Cerrahpasa \\ Cerrahpasa Faculty of Medicine \\ Child Health and Diseases Department, Istanbul, Turkey \\ E-mail: nevnuraydilek35@gmail.com \\ Nevin Hotun Sahin \\ Istanbul University-Cerrahpasa \\ Florence Nightingale Nursing Faculty, \\ Departmant of Women Health and Disease Nursing, Istanbul, Turkey \\ E-mail: nevinsahin34@yahoo.com
}

\begin{abstract}
Breast milk is the most significant source of nutrition for the health and development of a newborn. Breastfeeding has a great importance for healthy growth and development of the newborn. The World Health Organization (WHO) and the United Nations Children's Aid Fund (UNICEF) recommend that newborns should be fed with only breastmilk during the first six months of their lives because of the nutritional and immunological benefits of breastmilk and, followed by breastfeeding with additional nutrients up to two years.

Many studies have been conducted on the effects of sociodemographic variables, feeding and lifestyle habits on breast milk content. The results showed that many harmful chemicals were found in the content of breast milk. The chemicals in cleaning materials, cosmetic products and pesticides that are frequently used in daily life are absorbed through the skin or enter our bodies via respiratory and oral ways.

After reaching a certain threshold value, they show the effects. These effects also vary according to the type of substance exposed, the duration of exposure, the $\mathrm{pH}$ value, the solubility, the way of taking and the amount taken. In addition, some elements may cause more harm to the body by showing synergistic effects with other chemicals.

The most sensitive periods are pregnancy, puberty, and infancy in terms of being exposed to harmful chemicals and industrial substances. The harms of these chemicals, encountered during pregnancy, cannot be prevented by the placenta and may cause developmental disorders in the endocrine system or many systems of the fetus.

It is very difficult to remove persistent organic pollutants and heavy metals contained in industrial and chemical products. The majority of these are lipophilic, ie they accumulate in adipose tissue. The toxic chemicals that the mother has been exposed before are also a potential risk for babies who are fed with breast milk in the early period when there is rapid growth and development after birth.

Toxic substances indirectly effect various systems such as nervous, reproduction, respiration and endocrine by causing stimulation or suppression of immunomodulatory components. In some studies, delayed neurological development of children has been associated with mothers' exposure to heavy metals $(\mathrm{Pb}, \mathrm{Hg}$, etc.) and persistent organic pollutants. Health care providers should advice women about avoiding potential pollutants during pregnancy and post-pregnancy and the issues that women should pay attention during lactation.

The aim of this compilation is to review the literature on industrial and chemical products effecting breast milk content and to contribute to the awareness of health care providers.
\end{abstract}

Keywords: Breast milk, breastfeeding, industrial products, chemical products, Toxic chemicals.

DOI: $10.7176 / J S T R / 6-05-09$ 


\title{
Endüstriyel ve Kimyasal Ürünlerin Anne Sütü İçeriğine Etkisi
}

\begin{abstract}
Özet
Anne sütü, yenidoğan bebeğin sağlığı ve gelişimi açısından en önemli besin kaynağıdır. Dünya Sağlık Örgütü (DSÖ) ve Birleşmiş Milletler Çocuklara Yardım Fonu (UNICEF), anne sütünün besinsel ve immünolojik yararları dolayısıyla yaşamın ilk altı ayında yalnızca anne sütü sonrasında ise ek besinler ile birlikte iki yıla kadar emzirmenin devam edilmesini önermektedir.

Anne sütü içeriğine yönelik çalışma analizlerinde birçok zararlı kimyasal maddeye rastlanmıştır. Günlük yaşamda sıkça kullanılan; temizlik ve kozmetik ürünlerinin ve tarım ilaçlarının içeriğindeki bu maddeler vücuda, deriden emilerek, solunum ya da ağız yoluyla girmekte ve belli bir eşik değerine ulaştıktan sonra etkisini göstermektedir. Bu etkiler; maruz kalınan maddenin cinsine, $\mathrm{pH}$ değerine, çözünürlüğüne, vücuda alınma şekline, alınan miktara ve maruz kalınan süreye göre değişiklik göstermektedir. Ayrıca bazı elementler, diğer kimyasallarla sinerjik etki göstererek vücuda daha fazla zarar verebilmektedir.

Zararlı kimyasal ve endüstriyel maddelerle karşılaşma açısından en hassas dönemler süt çocukluğu, puberte dönemi ve gebeliktir. Gebelikte karşılaşılan bu kimyasal maddeler, plasenta tarafindan zararsız hale getirilememekte ve fetüsün özellikle endokrin olmak üzere pek çok sisteminde gelişme bozukluklarına yol açabilmektedir.

Endüstriyel ve kimyasal ürünlerin içeriğinde bulunan kalıcı organik kirleticiler ve ağır metallerin ortamdan uzaklaştırılması çok zordur. Bunların büyük çoğunluğu lipofiliktir, yani yağ dokusunda birikirler. Annenin vücudunda, daha önceki maruziyetlerle biriken toksik kimyasal maddeler, doğum sonrası hızlı büyüme ve gelişmenin olduğu erken dönemde anne sütü ile beslenen bebekler için de potansiyel bir risk oluşturmaktadır. Toksik maddeler, immünomodülatör bileşenlerin uyarılmasına veya baskılanmasına neden olarak sinir, üreme, solunum ve endokrin gibi çeşitli sistemleri dolaylı olarak etkilerler. Yapılan bazı çalışmalarda çocukların nörolojik gelişimlerinin gecikmesi annelerin ağır metallere ( $\mathrm{Pb}, \mathrm{Hg}$ v.b) ve kalıcı organik kirleticilere maruz kalmaları ile ilişkilendirilmiştir.

Sağlık bakımı sunucuları, gebelik ve sonrası dönemlerde kadınların bu potansiyel kirleticilerden uzak durması ve emzirme dönemlerinde dikkat etmesi gereken konulara yönelik danışmanlık yapmalıdır.

$\mathrm{Bu}$ derlemenin amacı, anne sütü içeriğine etki eden endüstriyel ve kimyasal ürünler konusunda literatürü incelemek ve sağlık bakımı sunucularının bu konuda farkındalık geliştirmesine katkıda bulunmaktır.
\end{abstract}

Anahtar kelimeler: Anne sütü, emzirme, endüstriyel ürünler, kimyasal ürünler, toksik kimyasallar.

\section{Giris}

Anne sütü, yenidoğan bebeğin sağlığı ve gelişimi açısından en önemli besin kaynağıdır. Yenidoğanın büyüme ve gelişimi için doğumdan itibaren anne sütü ile beslenmesi büyük önem taşımaktadır. Doğumdan sonra ilk altı ay bebeğin fizyolojik ve psiko-sosyal ihtiyaçlarını anne sütü tek başına karşılamaktadır (Andreas ve ark., 2015; Kulinich ve Liu, 2016; Lönnerdal, 2016; Mandal ve ark., 2014; Nonqonierma ve Gerald, 2015). Anne sütünün besinsel ve immünolojik yararları nedeni ile Dünya Sağlık Örgütü (DSÖ) ve Birleşmiş Milletler Çocuklara Yardım Fonu (UNICEF) yaşamın ilk altı ayında yalnızca anne sütü ile beslenmenin ve sonrasında ek besinler ile birlikte iki yıla kadar emzirmenin devam etmesinin gerekliliğini önemle vurgulamaktadır (Chao ve ark., 2014; Islam ve ark., 2014). Ülkemizde, TC. Sağlık Bakanlı̆ğ tarafindan bu önerilere uygun olarak ülke çapında anne sütünü yaygınlaştırmaya yönelik çalışmalar gerçekleştirilmektedir.

Anne sütü içeriğini etkileyen değişkenlere yönelik birçok çalışma yapılmıştır. Son yapılan çalışmalarda bazı ilaçların, ağır metallerin, pestisitlerin ve organik çözücülerin anne sütüne geçtĭgi belirlenmiştir (Andreas ve ark., 2015; Gallego ve ark., 2016; Mandal ve ark., 2014; Matos ve ark., 2015; Lignell ve ark., 2013; Vigh ve ark., 2013; Čechová ve ark., 2017; Zhang ve ark.,; 2017; Asamoah ve ark.; 2018; Tirisina ve ark., 2017; Antignac ve ark., 2016; Szmyt ve ark., 2019).

İnsan sağlığına zararlı olan kimyasal maddelerle karşılaşmak açısından en hassas dönemler süt çocukluğu, puberte dönemi ve gebeliktir. Gebelikte karşılaşılan bu kimyasal maddeler, plasenta tarafindan zararsı hale getirilememekte ve fetusun özellile endokrin olmak üzere pek çok sisteminde gelişme bozukluklarına yol açabilmektedir (Durmaz ve Özmert, 2010; Szmyt ve ark., 2019). 


\subsection{Toksik kimyasallar}

Anne sütü ile beslenen bebeklerde, annenin daha önce maruz kaldığ toksik kimyasal maddeler bebek için de potansiyel bir risktir (Solomon ve ark., 2002). Doğum sonrası erken dönemde hızlı bir büyüme ve gelişme dönemi olduğundan beslenme, toksik elementlerle ilgili riski bebeklik döneminde çok daha önemlidir (Saraçoğlu ve ark., 2007).

Sanayileşme, kentleşme, modernizasyon ve de buna bağlı gelişen kimya ve imalat sektörü ile birlikte insanların tüketim alışkanlıkları ve ihtiyaçları değişmekte, yeni ihtiyaçlar neticesinde günlük yaşamda birçok endüstriyel ve kimyasal ürün günlük yaşamın içerisine girmektedir. Günlük yaşamda sıkça kullanılan temizlik maddelerinin, kozmetik ürünlerinin ve tarım ilaçlarının içeriğinde birçok kimyasal ve endüstriyel madde mevcuttur. Bu maddeler vücudumuza deriden emilerek, solunum ya da ağız yoluyla girmekte, belli bir eşik değerine ulaştıktan sonra etkisini göstermektedir. Bu etkiler, maruz kalınan maddenin cinsine, maruz kalınan süreye, $\mathrm{pH}$ değerine, çözünürlüğüne, vücuda alınma şekline ve alınan miktara göre de değişiklik göstermektedir. Ayrıca bazı elementler, diğer kimyasallarla sinerjik etki göstererek vücuda daha fazla zarar verebilmektedir (Man, Y.B., 2017; Bakar ve Baba, 2009).

\subsection{Kozmetikler}

Kozmetikler, içerisindeki kimyasal maddeler nedeniyle oldukça karmaşık bir yapıya sahiptir (Borlu, 2012). Kozmetikler, tedavi edici özelliği olmayan, temizleyici veya cildin görünümünü düzeltici olan bileşiklerdir (Çomoğlu, 2012). Kozmetiklerin içerisinde bulunan maddelerin bir kısmının düşük toksisiteye sahip olduğu ve güvenli bir şekilde kullanılabileceği ifade edilirken, bazı bileşimlerin güvenilirliği ve yan etkileri yeterince bilinmemektedir (Castanedo-Tardan, 2009;Russ, 2009). Kozmetiklerin içerisinde yer alan ve sağllğı bozan bu sentetik kimyasallar; endokrin bozucular, ağır metaller, petrokimyasallar ve irritanlar olarak dört grupta ele alınabilmektedir (Koo, 2004). Örneğin oje, losyon, sabun, temizleyiciler, saç bakım ürünleri, oda spreyleri gibi pek çok kozmetik ürünün içerisinde yer alan fitalat (2-etilhekzil) maddesi ya da onun monoester metabolitleri ile gebelik döneminde karşılaşıldığında, fetüsün üreme sisteminde anomaliler meydana gelebilmektedir. Fitalat maddesinin germ hücrelerine zarar verdiği, testesteron ve epididimal spermatozoa seviyesini azalttığı, bağışıklık ve solunum sistemini de olumsuz yönde etkilediği belirlenmiştir (Koniecki, 2011). Ayrıca kullanılan kozmetik ürünlerin çeşitliliği artıkça da maruz kalınan fitalat miktarının da arttığ ve bu durumun sağlı̆̆ etkilediği vurgulanmaktadır (Russ, 2009). Güney Kore'de yapılan bir araştırmada, dört farklı kategoride (saç bakım ürünü, deodorant, parfüm ve oje) yer alan kozmetikler incelendiğinde, 102 ürünün içerisinde fitalat maddesine rastlanıldığı tespit edilmiştir (Koo, 2004). Parllet ve arkadaşlarının 2013'de yaptıkları çalışmada kadınların kullandıkları günlük bakım ürünleri ile idrar fitalat konsantrasyon düzeyini karşılaştırmışlardır. Tırnak parlatıcılar, deodorantlar, parfüm kullananlarda özellikle parfüm kullananlarda, fitalat konsantrasyonunun daha yüksek olduğu saptanmıştır (Çetinkaya, 2009).

\subsection{Temizlik malzemeleri}

Evlerde kullanılan temizlik malzemeleri birçok kimyasal madde içermektedir. Bunlardan bazıları toksik özellikteki kimyasallardır. Temizlik malzemelerinin kullanımı ile bu kimyasalların büyük bir kısmı kanalizasyona akıp buradan toplayıcı su ortamlarına ve de toprağa ulaşabilir. Çevresel anlamda yarattığ kirliliğin yanı sıra, temizlik malzemeleri hem temizliği yapan hem de aynı ortamı paylaşan bireyler için sağlık riski oluşturabilir. Çünkü temizlik malzemelerinin içerebileceği kimyasallar, kimyasal yanma, deri ve gözde tahriş, solunum yolları tahrişi veya çocuklarda ve yetişkinlerde astım atakları gibi akut zararlara veya bunlara uzun süre maruz kalan bireylerde kronik zararlara yol açabilmektedir (Inform Inc, 2006). Örneğin, sprey boyalar, fırın temizleyiciler, dezenfektanlar, mobilya parlatıcıları ve diğer tüm sprey ürünler, soluyacağımız havanın bir parçası olabilir. Başta temizlik yapan kişi olmak üzere aynı evde yaşayan tüm bireyler solunum ve deri yoluyla hava ortamındaki bu kimyasallara maruz kalabilmektedir (Karapınar, 2015).

Deterjan yüzey-aktif madde dışında önemli oranda (\%70-90) katkı maddeleri içerir. Bunlar; temizleyici, beyazlatıcı, yumuşatıcı, korozyon önleyici, köpürtücü, parlaklık verici, koku verici ya da antiseptik özellik veren katkı maddeleridir. Evlerde temizlik ve hijyen amaçlı, sabun ve deterjan gibi temizleyici özellikteki malzemeler dışında, bir çok farklı temizlik maddesi kullanılmaktadır. Bunların arasında en yaygın kullanılanı çamaşır suyu gibi ağartıcı ve dezenfektanlar ile tuz ruhu gibi asitler yer almaktadır. Ev ve/veya arabalarda kullanılan hava tazeleyici ürünler, kokunun uzun süre kalıcı olmasını sağlamak için kullanılan fitalat gibi kimyasallar içerebilir. Fitalatlara sürekli maruz kalınırsa endokrin, doğurganlık, obezite, astım, alerjik semptomlar ve gelişim problemleri riskini artabilmektedir (Karapınar, 2015; Katsikantami ve ark., 2016).

96 | P a g e

www.iiste.org 
İngiltere'de 7000 aile üzerinde yapılan bir araştırma hamileyken ya da doğumdan hemen sonra evde dezenfektan, koku giderici gibi kimyasal ürünlerin çok sık kullanımının çocukların akciğerlerine zarar verebileceğini ortaya çıkarmıştır (Henderson, 2008). Araştırmalar her beş anneden dört'ünün dezenfektan ve ağartıcılar gibi temizlik malzemelerinin, her üç evden iki'sinde de cam temizleyiciler, hava yenileyiciler ve aerosollerin kullanıldığını göstermiştir (Karapınar, 2016). Deterjan maddeleri (çamaşır, bulaşık deterjanları, halı temizleyicileri, cam siliciler v.b) tarım ilaçları ve bunların içeriğindeki kimyasal ve ağır metaller vücudumuza deriden emilerek, solunum ya da ağız yoluyla girmekte ve vücudumuzda birikmektedir. Ülkemizde de hijyen amaçlı kimyasalların etkilerini ortaya koymak için yapılmış geniş kapsamlı bir çalışma olmadığı ancak yurtdışında hazırlanan raporda yaygın kullanılan ürünlerde görülen 17 bin kimyasalın sadece yüzde 30’u insan sağlığı açısından test edildiği ortaya çıkmıştır (Özkan ve Hurma, 2011).

\subsection{Pestisitler}

Pestisitler, DSÖ tarafından insan veya hayvan hastalıklarını taşıyan canlılar dahil olmak üzere gıda, tarımsal ürün, ağaç ve orman ürünleri veya hayvan yemlerinin üretimi, işlenmesi, depolanması, taşınması veya satışı sırasında istenmeyen zararlı etkilere neden olabilecek canlıları kaçırtmak, öldürmek ya da kontrol etmek amacı ile kullanılır. Hayvanların üzerinde veya içinde bulunan böcek, eklem bacaklı ve zararlı canlıları kontrol etmek amacı ile hayvanlara uygulanabilen virüsler dahil olmak üzere mikroorganizmalar veya herhangi bir madde ya da madde karışımları pestisit olarak tanımlanmaktadır (WHO-2010). İnsanlar pestisitlere özellikle beslenme ya da daha nadir olarak inhalasyon yolu ile maruz kalmaktadırlar. $\mathrm{Bu}$ maruziyetin \%90'ı besin yoluyla olmaktadır. Lipofilik özellikte ve parçalanmaya karşı dirençli olan tarım ilaçları uzun yarı ömürleri nedeniyle günlük beslenmeyle alınarak kan, süt ve yağ dokusunda birikebilen maddelerdir. Bebekler plasental geçiş ya da anne sütü ile pestisitlere maruz kalmaktadırlar. Anne karnında plasenta yoluyla organik birikicilere maruz kalan fetüs; laktasyon sırasında duktal sistem ile birleşen yağ dokusu aracıllğg ile anne sütüne geçen organik birikicilere beslenme sırasında yeniden maruz kalır (Mokarizadeh, 2015).

Tarım ilaçlarının insan vücudunda birikebilme özellikleri nedeni ile sağlık üzerinde birçok olumsuz etkisi mevcuttur. Nörogelişimsel gecikmelere (Čechová ve ark., 2017; Kim ve ark., 2018; Shelton ve ark., 2014) ve zayıf östrojenik/anti östrojenik etkiler ile çeşitli düzeyler de endokrin bozukluklarına, preterm düşük doğum ağırlıklı bebeklere ve immüno toksiteye yol açabilmeleri nedeniyle insan sağlığı için önem arz etmektedirler (Bahadar ve ark., 2015; Mokarizadeh ve ark., 2015).

Annenin yaşadığ 1 yer ile anne sütü pestisit düzeyleri arasında pozitif ilişki olduğunu gösteren birçok çalışma mevcuttur. Yapılan çalışmaların çoğu tarım işçisi anneler üzerinde yapılmıştır. Aytaç ve ark., yaptıkları çalışmada 59 anneden alınan süt örneklerinin 37 (\%62.5)'sinde, Öztekin ve arkadaşlarının 80 tarım işçisi anne ile yaptıkları çalışmada 77 (\%96) 'sinde çok yüksek oranda pestisit kalıntısına rastlanmıştır.

Yapılan çalışmalar yenidoğan döneminde pestisit düzeyi yüksek saptanan çocukların okul öncesi dönem de sosyal ve davranışsal problemleri olabileceğini göstermiştir. Pestisitlerin özellikle santral sinir sistemi üzerine etkileri belirgin olması nedeniyle bu annelerin sütü ile beslenen çocukların nörolojik gelişimlerinin yakın takip edilmesi gerekmektedir (Ribas-Fitó, 2007).

Meksika, Tayland, Çin ve Vietnam gibi tropikal ülkelerde sitma mücadelesi nedeni ile sürekli pestisit kullanımı sonucu anne sütünde bulunan toplam pestisit miktarı yüksek düzeylerdedir. Bunun yanın da Almanya, İsviçre, Japonya ve İngiltere gibi gelişmiş ülkelerde birçok pestisit türü yasaklanmıştır (Şahin, 2009; Solomon ve Che, 2002).

\subsection{Toksik A ğır Metaller}

Fiziksel özellik açısından yoğunluğu $5 \mathrm{~g} / \mathrm{cm}^{3}$ ten daha yüksek olan metaller ağır metaldirler. Tıpta ise ağır metal tanımı, elementlerin atomik ağırlıklarına bakılmaksızın tüm toksik özelliği taşıyan metaller olarak tanımlanır (Aslam ve ark., 2011; Ağcasulu ve ark., 2007; Kahvecioğlu ve ark., 2009).

Bazı metaller insan vücudu için vazgeçilmez iken bazıları da ileri derecede zehirleyicidirler. Ancak vücut için faydalı görünen metallerin de belirli miktarlardan sonra toksik etkili oldukları bilinmektedir. Organların hızlı gelişimi ve fonksiyonlarını kazanmaları yenidoğan döneminde de devam eder. Bu dönemde merkezi sinir sistemi hızlı bir büyüme oranına sahiptir ve ağır metallerin toksik etkilerine karşı son derece savunmasızdır (Özçetin ve ark., 2013).

Ağır metaller vücuda; ağız, solunum ve deri yolu ile alınmaktadır. Vücuda eser miktarlarda alınsalar bile metabolizmadan dışarı çok yavaş atıldıklarından zamanla birikerek tehlikeli doza ulaşırlar (Farooq ve ark., 2008). Ağır metallerin vücutta oluşturacağı etkiler, ağır metalin derişimine bağlı olmanın yanı sıra metal 
iyonunun yapısına, çözünürlük değerine, kimyasal yapısına, redoks ve kompleks oluşturma yeteneğine, vücuda alınış şekline ve çevrede bulunma sıklığına bağlıdır. En fazla toksik etki gösteren ağır metallerin başında civa, kurșun, kadmiyum ve bakır gelmektedir (İstanbulluoğlu, 2011).

Son yıllardaki teknolojik gelişmeler yaşam koşullarını eskisine göre çok kolaylaştırmasının yanı sıra, çevre kirliliğinde büyük bir artışa sebep olmaktadır. Bununla birlikte, doğal kaynakların fazlasıyla duyarsız kullanılması ve modern toplumların sanayi atıklarının sonucunda ise hava, toprak, su ve gıda kirliliği meydana gelmektedir (Saad ve Hassanien, 2001). Hem mesleki ve hem de çevresel maruziyet sonucu özellikle kurşun, civa, kadmiyum ve arsenik gibi ağır metaller insan sağlığ 1 için önemli potansiyel tehdit oluşturmaktadır $(\mathrm{Hu}, 2000)$. Bununla birlikte, endüstriyel işlem ve ürünlerde ağır metal kullanımı son yıllarda hızla artmış, bunun yanında insanlar evde, dışarıda, birçok iş sahasında her gün ağır metallerin etkisine maruz kalmakta ve buna bağlı olarak da insanlar üzerindeki etkisi de tehlikeli değerlere ulaşmaktadır. Bu maruziyet sonucu çok ciddi sağlık sorunlarına neden olmaktadır ve diğer ülkelerin yanı sıra Türkiye'nin de önemli bir sağlık sorunu haline gelmektedir.

Kimyasallar içerisinde ağır metaller önemli bir yer teşkil etmektedir. (Demir ve ark., 2014) tarafindan kozmetik ürünlerdeki ağır metallerin varlığının ve miktarlarının belirlenmesi amacıyla yapılan çalışmada incelenen 10 saç boyası ve 10 ojede kurşun $(\mathrm{Pb})$ ve kadminyum $(\mathrm{Cd})$ bulunduğu belirlenmiştir (Selevan, 2004). Yapılan çalışmalarda anne sütünde en fazla civa, kurşun, kadminyum ve arseniğe rastlanmıştır (Szmyt, 2019).

Toksik ağır metallerin anne sütündeki miktarları giderek daha da önem kazanmaya başlamıştır. Hemen bütün bebeklerin yaşamın erken dönemlerinde anne sütü aldıkları düşünüldüğünde, organizmanın toksik ağır metaller ile karşılaşması hayatının ilk aylarına kadar geriye gitmiştir. Alınan toksik ağır metaller bir vücut dokusu veya organ içinde birikir ve hayatın belli bir döneminde zararlı etkileri ortaya çıabilir. Bu nedenle kişilerin özellikle de emziren annelerin temiz bir çevrede yaşamaları, doğal ve sağlıklı beslenme konusunda gerekli bilince erişmeleri daha da önem kazanmaktadır.

\section{Sonuç ve Öneriler}

Anne sütü ile beslenen yenidoğanlarda, annenin daha önce maruz kaldığı toksik kimyasal maddelerin bebek içinde potansiyel bir risk olduğu unutulmamalıdır. Kimyasal ve endüstriyel maddelerin günlük yaşamda kullandığımız birçok temizlik, kozmetik, tarım ilaçları, tüketilen gıdaların içeriğini oluşturmaktadır. Bu ürünlerin hedef kitlesi olan kadınların ve sağlık çalışanlarının konuyla ilgili farkındalıklarının ve bilgi düzeylerinin artırılması gerekmektedir. Bu konuda daha fazla bilimsel araştırma ve yayınların yapılması, toplumsal bilincin oluşması için üretim ve denetim mekanizmalarının oluşturulması, çevreye karşı duyarlılığın geliştirilmesi için konuyla ilgili eğitimlerin yapılması sağlıklı bireylerin yetiştirilmesine katkı sağlayacaktır. Böylece toplumun genel sağlık düzeyi ve kalitesi yükselecek, sağlıklı nesiller yetişecek ve ülke ekonomisi olumlu etkilenecektir.

\section{Kaynaklar}

1. Andreas,NJ., Kampmann, B., Mehring Le-Doare, K. (2015). Human breast milk: A review on its composition and bioactivity. Elsevier Ireland Ltd. All rights reserved.

2. Kulinich, A., Liu, L. (2016). Human milk oligosaccharides: The role in the fine-tuning of innate immune responses. Elsevier Ltd. All rights reserved

3. Lönnerdal B .(2016). Bioactive proteins in human milk: health, nutrition, and implications for infant formulas. J Pediatr 173:S4-S9

4. Mandal SM, Bharti R, Porto WF, Gauri SS, Mandal M, Franco OL, Ghosh AK .(2014). Identification of multifunctional peptides from human milk. Peptides 56:84-93

5. Nonqonierma AB, FlitzGerald RJ .(2015). Bioactive properties of milk proteins in humans: a review. Peptides 73:20-34 
6. Chao HH, Guo CH, Huang CB, Chen PC, Li HC, Hsiung DY, Chou YK .(2014). Arsenic, cadmium, lead, and aluminium concentrations in human milk at early stages of lactation. Pediatr Neonatol 55(2): $127-134$

7. Islam MR, Attia J, Alauddin M, McEvoy M, McElduff P, Slater C, Islam MM, Akhter A, d'Este C, Peel R, Akter S, Smith W, Begg S, Milton AH (2014) Availability of arsenic in human milk in women and its correlation with arsenic in urine of breastfed children living in arsenic contaminated areas in Bangladesh. Environ Health 13(101):1-10

8. Gomez-Gallego C, Garcia-Mantrana I, Salminen S, Collado MC .(2016). The human milk microbiome and factors influencing its composition and activity. Semin Fetal Neonatal Med 21(6):400-405

9. Matos C, Ribeiro M, Guerra A. (2015). Breastfeeding: antioxidative properties of breast milk. J Appl Biomed 13(3):169-180

10. Lignell S, Aune M, Darnerud PO, Hanberg A, Larsson SC, Glynn A (2013) Prenatal exposure to polychlorinated biphenyls (PCBs) and polybrominated diphenyl ethers (PBDEs) may influence birth weight among infants in a Swedish cohort with background exposure: A cross-sectional study. Environ. Health 12:44

11. Vigh É, Colombo A, Benfenati E, Håkansson H, Berglund M, Bódis J, Garai J. (2013). Individual breast milk consumption and exposure to PCBs and PCDD/Fs in Hungarian infants: a time-course analysis of the first three months of lactation. Sci Total Environ 449:336-344

12. Čechová, E., Scheringer, M., Seifertová, M., Mikeš, O., Kroupová, K., Kuta, J., Forns J, Eggesbø, M., Quaak I, de Cock, M., vande Bor M, Henrieta Patayová H, Palkovičová Murínová L, Kočan A (2017) Developmental neurotoxicants in human milk: comparison of levels and intakes in three European countries. Sci Total Environ 579:637-645

13. Zhang L, Shuaixing Y, Zhao Y, Shi Z, Li J,Wu Y. (2017). Polybrominated diphenyl ethers and indicator polychlorinated biphenyls in human milk from China under the Stockholm Convention. Chemosphere 189:32-38

14. Asamoah A, Essumang DK, Muff J, Kucheryavskiy SV, Søgaard EG .(2018). Assessment of PCBs and exposure risk to infants in breast milk of primiparae and multiparae mothers in an electronic waste hot spot and non-hot spot areas in Ghana .Sci Total Environ 612:1473-1479

15. Tirisina A, Sircu R, Pinzaru I, Bahnarel I .(2017). Changes over time in persistent pollutants (POP) concentrations in human milk in the Republic of Moldova. Toxicol Environ Chem 99(5-6):1007-1019

16. Szmyt, M.P., E., Darol, S.E., Kopciuch, R.G.(2019). The impact of environmental pollution on the quality of mother's milk. Environmental Science and Pollution Research https://doi.org/10.1007/s11356-019-04141-1

17. Durmaz, E., Elif N. Özmert, N.E., Erkekog, P., Belma Giray, B., Derman, O., Filiz Hıncal, F., Kadriye Yurdako, K., Samur, G. (2010). Plasma Phthalate Levels in Pubertal Gynecomastia. PEDIATRICS Volume 125, Number 1, www.aappublications.org/news by guest on September 10, 2019

18. Saracoglu, S., Saygi, K., Özgür, O., Uluozlu, D., Tuzen, M,, Soylak, M.(2007). Determination of trace element contents of baby foods from Turkey. Food Chem, 105:280-5

19. Bakar, C., Baba, A. (2009) Metaller ve insan sağlığı:yirminci yüzyıldan bugüne ve geleceğe miras kalan çevre sağlığı sorunu. I. Tıbbi Jeoloji Çalıştayı, Ürgüp/Nevşehir:. p. 162-185. 
20. Borlu, M.(2012). Kozmetiklerle oluşan kontakt alerji paternleri. Türkiye Klinikleri Journal of Cosmetic Dermatology Special Topics.; 5(1): 87-93.

21. Çomoğlu, T. (2012).Kozmetikler. Marmara Pharmaceutical Journal.16: 1-8.

22. Castanedo-Tardan, M.P., Zug, K.A.(2009). Patterns of cosmetic allergy. Dermatologic Clinics. 27(3): 265-280, vi.

23. Russ, K. (2009). Health effects of personal care products. a review of the evidence. Nursing for Women's Health..13(5): 392-401.

24. Koniecki, D., Wang, R., Moody, R.P., Zhu, J. (2011). Phtalate in cosmetic and personal care products: concentrations and dermal exposure. Environmental Research.111: 329-336.

25. Koo, H.J., Lee, B.M. (2004).Estimated exposure to phthalates in cosmetics and risk assessment. Journal of Toxicology and Environmental Health. 67(23-24): 1901-1914.

26. Çetinkaya, S. (2009). Endokrin bozucular ve ergenlik üzerine etkileri. Dicle Tıp Dergisi, 36(1), 5966.

27. Parlett, L.E., Calafat, A.M., Swan, S.H. (2013). "'Women's exposure to phthalates in relation to use of personal care products", Journal of Exposure Science and Environmental Epidemiology, 23, pp.197-206

28. Inform Inc. (2006). Fact sheet: Studies of health impacts associated with cleaning products.

29. Karapınar, N.(2015). Temizlik Malzemelerindeki Tehlike Daha Temiz Olmak Adına Çevre ve Sağı̆̆ımızı mı tehtit ediyoruz?. Maden Tetkik ve Arama Genel Müdürlüğü, Deniz ve Çevre Araştırmaları Dairesi Başkanlığı, Ankara. http://www.mta.gov.tr/v3.0/sayfalar/hizmetler/kutuphane/ekonomi Erişim 10.09.2019

30. Dökmeci, İ. (2010). Çevre sağlı̆̆1 ve Deterjanlar,Naturelife, sayı 42.

31. Katsikantami, I., Sifakis, S", Tzatzarakis, M.N., Vakonaki, E., Kalantzi, O.I., Tsatsakis, A.M., Rizos, A.K. (2016). A global assessment of phthalates burden and related links to health effects, 97;212-232

32. Özkan, S., Hurma, S.(2011). Hastane temizliğinde kullanılan kimyasallarla ilgili bilgilendirme eğitiminin çalışanların temizlik maddeleri ve bunların doğru kullanımı hakkındaki bilgilerine etkisi. III. Uluslar arası Sağlıkta Performans ve Kalite Kongresi, Poster Bildiriler Kitabı, Eds.: Beylik U., Önder Ö., Güler H., Öztürk A., Ankara. s.37-52.

33. WHO. Guidelines on public health pesticide management policy. SEA-CD-214. New Delhi: World Health Organization (WHO), Regional Office for South-East Asia; 2010. http://www.who.int/whopes/resources/SEA_CD_214.pdf (Erişim tarihi: 30.07.2018)

34. Aytaç, N., Hilal, A., Yapıcıŏlu, A.B., Dağlığlu, N., Gülmen, M.K., Tanır, F.(2010). Organocohlorine pesticide level in breast milk. Turkiye Klinikleri J Med Sci;30(1):107-14.

35. Longnecker, M.P., Wolff, M.S., Gladen, B.C., Brock, J.W., Grandjean, P., Jacobson, J.L., et al. (2003). Comparison of polychlori natedbip henyllevels acrossstu dies of human neu ro development. Environ Health Perspect;111(1):65-70. 
36. Kim, S., Eom, S., Kim, H-J., Lee, J.J., Choi, G., Choi. S., Kim, S., Kim, S.Y., Cho, G., Kim, Y.D., Suh, E., Kim, S.K., Kim, S., Kim, G.H., Moon, H.B., Park, J., Kim, S., Choi, K., Eun, S.H. (2018). Association between maternal exposure to major phthalates, heavy metals, and persistent organic pollutants, and the neurodevelopmental performances of their children at 1 to 2 years of age- CHECK cohort study. Sci Total Environ 624:377-384

37. Mokarizadeh, A., Faryabi, M.R., Rezvanfar, M.A., Abdollahi, M. (2015). Acomprehensive review of pesticides and the immune dysregulation: mechanisms, evidence and consequences. Toxicol Mech Methods 25(4):258-278

38. Öztekin, O., Köken, R., Bulut, S., Alpay, F. (2011). Afyonkarahisar İli Anne Sütü Pestisit Düzeylerinin Belirlenmesi ve Epidemiyolojik Etkilenimi. Turkiye Klinikleri J. Pediatr, 20(2):113-8.

39. Solomon, G.M., Weiss, P.M,. (2002). Chemical contaminants in breast milk: time trends and regional variability. Environ Health Perspect .110(6):A339-47.

40. Ribas-Fitó, N., Torrent, M., Carrizo, D., Júlvez, J., Grimalt, J.O., Sunyer, J.(2007). Exposure to hexach -lo robenzene during pregnancy and children's social behavior at 4 years of age. Environ Health Perspect, 115(3):447-50.

41. Alsam, B., Javed, I., Khan, H.F., Rahman, Z.(2011). Uptake of heavy metal residues from sewage sludge in the goat and cattle during summer season. Pak Vet J. 2011;31:75-7.

42. Kahvecioğlu, Ö., Kartal, G., Güven, A., Timur, S.(2009). Metallerin çevresel etkileri; Metalurji Dergisi, 136:47-53.

43. Farooq, M., Anwar, F., Rashid, U. (2008). Appraisal of heavy metal contents in different vegetables grown in the vicinity of an industrial area. Pak J Bot. 40:2099-106.

44. İstanbulluoğlu, H. (2011). Piyasada satılan süt ve süt ürünlerinde ağır metal kirliliği (Uzmanlık tezi). Ankara, Gülhane Askeri Tıp Akademisi,

45. HU, H. (2000). Exposure to metals. Prim. Care. 2: 983-996

46. Demir, N., Göktürk, T., Akçay, O. (2014). ' Bazı Kozmetik Ürünlerde Ağır Metal (Pb, Cd) Tayini'”, DU Journal of Science (E-Journal), 9 (2), pp.194-200.

47. Selevan, S.G., Rice, D.C., Hogan, K.A., Euling, S.Y., Pfahles, Hutchens, A., Bethel, J.(2003). 'Blood lead concentration and delayed puberty in girls", The New England Journal of Medicine, 348(285), pp.1527-1536. DOI: 10.1056/NEJMoa020880

48. Klaassen, C.D.(2009). Ağır Metaller ve Ağır Metal Antagonistleri (Konu:65), Brunton LL, Lazo JS, Parker KL(Editors), (Çeviri Editörü: Süzer Ö), Tedavinin Farmakolijik Temeli, Nobel Tıp Kitapevleri

49. Dökmeci, İ., Dökmeci, A.H., (2005). Toksikoloji Zehirlendirmede Tanı ve Tedavi, 4.Baskı, Nobel Tıp Kitabevleri,

50. Özkan G., 2009, Endüstriyel Bölge Komşuluğunda Kıyısal Kırsal Alandaki Hava Kalitesi; Muallimköy’de Partikül Madddede ve Topraktaki Ağır Metal Kirliliği, Yüksek Lisans Tezi, GYTE Fen Bilimleri Enstitüsüsü, Gebze, 9,12-22.

51. Patrick, L. (2003). Toxic metals and antioxidants: Part II. The role of antioxidants in arsenic and toxicity. Altern Med Rev. 8(2), 112-116. 
52. Anonymous.(2001). Summary of Evaluations Performed by the Joint FAO/WHO Expert Committee on Food Additives (JECFA),http://www.inchem.org/documents/jecfa/jeceval/jec_453.htm (Erişimtarihi:10 Mart 2019)

53. Man, Y.B., Chow, K.L., Xing, G.H., Chan, J.K.Y., Wu, S.C., Wong, M.H. (2017). A pilot study on health risk assessment based on body loadings of PCBs of lactating mothers at Taizhou, China, the world's major site for recycling transformers. Environ Pollut 227:364-371

54. Kim S, Eom S, Kim H-J, Lee JJ, Choi G, Choi S, Kim S, Kim SY, Cho G, Kim YD, Suh E, Kim SK, Kim S, Kim G-H, Moon H-B, Park J, Kim S, Choi K, Eun S-H (2018) Association between maternal exposure to major phthalates, heavy metals, and persistent organic pollutants, and the neurodevelopmental performances of their children at 1 to 2 years of age- CHECK cohort study. Sci Total Environ624:377-384

55. Shelton, J.F., Geraghty, E.M., Tancredi, D.J., Delwiche, L.D., Schmidt, R.J, Ritz, B., Hansen, R.L., Hertz-Picciotto, I. (2014). Neurodevelopmental disorders and prenatal residential proximity to agricultural pesticides: the charge study. Environ Health Perspect, 122(10):1103-1109.

56. Mokarizadeh, A., Faryabi, M.R., Rezvanfar, M.A., Abdollahi, M. (2015). A comprehensive review of pesticides and the immune dysregulation: mechanisms, evidence and consequences. Toxicol Mech Methods 25(4),258-278.

57. Koo, HJ, Lee, BM.(2004). Estimated exposure to phthalates in cosmetics and risk assessment. Journal of Toxicology and Environmental Health,. 67(23-24), 1901-1914. 